Allelochemicals: Biological Control of Plant Pathogens and Diseases 
Disease Management of Fruits and Vegetables

VOLUME 2

Series Editor:

K.G. Mukerji, University of Delhi, Delhi, India 


\title{
Allelochemicals: Biological Control of Plant Pathogens and Diseases
}

\author{
Edited by \\ INDERJIT \\ University of Delhi, India \\ and \\ K.G. MUKERJI \\ University of Delhi, India
}

畠 Springer 
A C.I.P. Catalogue record for this book is available from the Library of Congress.

ISBN-10 1-4020-4445-3 (HB)

ISBN-13 978-1-4020-4445-8 (HB)

ISBN-10 1-4020-4447-X (e-book)

ISBN-13 978-1-4020-4447-2 (e-book)

Published by Springer,

P.O. Box 17, 3300 AA Dordrecht, The Netherlands.

www.springer.com

Printed on acid-free paper

Cover photo:

Bio Control of powdery mildew pathogen Phyllactinia dalbergae on

Dalbergia sisoo by hyperparasite Cladosporium spongiosum.

(Microphotograph taken by Prof. K.G. Mukerji and Mr. S.K. Das)

\section{All Rights Reserved}

(C) 2006 Springer

No part of this work may be reproduced, stored in a retrieval system, or transmitted in any form or by any means, electronic, mechanical, photocopying, microfilming, recording or otherwise, without written permission from the Publisher, with the exception of any material supplied specifically for the purpose of being entered and executed on a computer system, for exclusive use by the purchaser of the work.

Printed in the Netherlands. 


\section{CONTENT}

Preface vii

1. Discovery and Evaluation of Natural Product-based 1 Fungicides for Disease Control of Small Fruits David E. Wedge and Barbara J. Smith

2. Allelochemicals as Biopesticides for Management of Plant-parasitic Nematodes

Nancy Kokalis-Burelle and Rodrigo Rodríguez-Kábana

3. Allelopathic Organisms and Molecules: Promising

Bioregulators for the Control of Plant Diseases,

Weeds, and Other Pests

Ana Luisa Anaya

4. The Impact of Pathogens on Plant Interference and Allelopathy

Scott W. Mattner

5. Allelopathy for Weed Control in Aquatic and Wetland Systems

Ramanathan Kathiresan, Clifford H. Koger, Krishna N. Reddy

6. Bacterial Root Zone Communities, Beneficial Allelopathies and Plant Disease Control

Antony V. Sturz

7. The Role of Allelopathic Bacteria in Weed Management Robert J. Kremer

8. The Allelopathic Potential of Ginsenosides Mark A. Bernards, Lina F. Yousef, Robert W. Nicol

9. Antimicrobial and Nematicidal Substances from the Root of Chicory (Cichorium intybus)

Hiroyuki Nishimura and Atsushi Satoh

10. Disease Resistance in Plants through Mycorrhizal Fungi Induced Allelochemicals Ren-sen Zeng

11. Allelochemicals from Ageratum conyzoides L. and Oryza sativa L. and their Effects on Related Pathogens Chuihua Kong

Index

List of Contributors 


\section{Preface}

Biological control of plant diseases and plant pathogens is of great significance in forestry and agriculture. There is great incentive to discover biologically active natural products from higher plants that are better than synthetic agrochemicals and are much safer, from health and environmental considerations. The development of natural products as herbicides, fungicides, and their role in biological control of plant disease promises to reduce environmental and health hazards. Allelopathic techniques offer real promise in solving several problems linked with biological control of plant pests. The allelopathic effect of plants on microorganisms, and microorganisms on microorganisms is of great environmental and economic significance. This book is organized around the premise that allelochemicals can be employed for biological control of plant pathogens and plant diseases. Specifically, this volume focuses on (i) discovery and development of natural product based fungicides for agriculture, (ii) direct use of allelochemicals as well as indirect effects through cover crops and organic amendments for plant parasitic pest control and (iii) application of allelopathy in the pest management.

In an effort to address above points, contributing authors provided up-to-date reviews and discussion on allelochemicals-related biological control of plant diseases and pathogens. Chapters 1 - 3 discuss discovery and development of allelochmicals and their role in the management of plant diseases. Chapter 4 discusses the effects of pathogens on the competitiveness and allelopathic ability of their hosts. Chapter 5 highlights the importance of allelopathy for weed control in aquatic ecosystems. Chapters 6-7 deal with bacterial potential in weed management and plant disease control. Chapter 8 describes the role of organic compound ginsenosides from rhizosphere soil and root exudates of american ginseng plant in control of fungal diseases. Antimicrobial and nematicidal substances from the rhizome of chicory has been discussed in Chapter 9. The role of allelochemicals induced in mycorrhizal plants in imparting disease resistance is given in Chapter 10. The last chapter discusses the biocontrol of plant pathogens and diseases by allelochmicals from Ageratum conyzoides a weed and rice plants has been highlighted in Chapter 11.

We are grateful to all authors for providing their valuable work to this volume. The articles are original and some have been written for the first time in any book. We are indebted to the following referees for their constructive comments and suggestions: Ana L. Anaya, Mark Bernards, Nancy Kokalis Burelle, Chester L. Foy, John M. Halbrendt, Robert Kremer, Azim Mallik, Susan Meyer, Reid J. Smeda, Tony Sturz, David Wedge and Jeff Weidenhamer. The editorial help of Ineke Ravesloot, Publishing Department, Springer is sincerely appreciated. It is our hope that this book will serve scientific community well, and equally hope that the book will stimulate young students to work on biological control of plant pathogens and diseases through natural allelochemicals.

Inderjit and K.G. Mukerji

October 2005 